Article

\title{
Synergistic effect of hydrogen bonding mediated selective synthesis of benzaldehyde in water
}

\author{
Zujin Yang, Hongbing Ji* \\ School of Chemistry and Chemical Engineering, Key Laboratory of Low-carbon Chemistry \& Energy Conservation of Guangdong Province, Sun Yat-sen \\ University, Guangzhou 510275, Guangdong, China
}

A R T I C L E I N F O

Article history:

Received 23 November 2013

Accepted 3 January 2014

Published 20 April 2014

\section{Keywords:}

$\beta$-cyclodextrin-functionalized cellulose

Hydrogen bonding

Synergistic effect

Cinnamaldehyde oxidation

Benzaldehyde

\begin{abstract}
A B S T R A C T
$\beta$-cyclodextrin-functionalized cellulose was prepared from cellulose and $\beta$-cyclodextrin crosslinked with epichlorohydrin. The supramolecular polymer has been used as a heterogeneous catalyst for the synthesis of benzaldehyde under mild reaction conditions with high activity and yield. The catalyst was easily recovered and reused without significant activity loss. The $\beta$-cyclodextrin in the polymer formed host-guest complexes with cinnamaldehyde via noncovalent bonding. In addition, multiple interactions were observed between $\beta$-cyclodextrin and the substrate via intermolecular $\mathrm{O}-\mathrm{H} \cdots \mathrm{O}$ hydrogen bonding. The significant promotion for the catalytic performance could be attributed to the synergistic effects of hydrogen bonding.
\end{abstract}

(C) 2014, Dalian Institute of Chemical Physics, Chinese Academy of Sciences. Published by Elsevier B.V. All rights reserved.

wide variety of compounds in the cavity to form inclusion complexes in solution or in the solid state $[9,10]$. The selective association of target molecules by $\beta-C D$ is extremely similar to the molecular recognition of a substrate by an enzyme. $\beta$-CD has been used to catalyze a number of chemical reactions via. non-covalent bonding, and has demonstrated enzyme-like specificity and selectivity [11-13]. Recent reports have indicated that the presence of hydrogen bonds between $\beta$-CD and the substrate results in a significant improvement in the reaction selectivity [14-16]. However, $\beta$-CD is not a good model for enzyme catalysis because $\beta$-CD has limited catalytic activity due to the weak intermolecular interactions between $\beta$-CD and the substrate. If the catalytic site could have the synergistic effects of more functional groups, recognition should be more precise, and more like what is seen in enzyme recognition [17-19]. But

\footnotetext{
* Corresponding author. Tel: +86-20-84113658; Fax: +86-20-84113654; E-mail: jihb@mail.sysu.edu.cn

This work was supported by the the National Natural Science Foundation of China (21376279, 21176268, 21036009), the Science and Technology Major Program of Guangdong Province (2012A080103005), and Special Project on Integration of Production, Education And Research of Guangdong Province (2011B090400439).
} 
to the best of our knowledge, $\beta$-CD derivatives based on the synergistic effects of multiple hydrogen bonds have not been applied to organic reactions, despite some reports on the acceleration of reaction rates and obvious enhancements in selectivity [20-22].

In the present study, $\beta$-cyclodextrin-functionalized cellulose polymer $(\beta$-CDCP) has been developed to investigate the production of natural benzaldehyde under mild conditions by the synergistic effects of additional weak interactions e.g. hydrogen-bonding between the polymer and the substrate (Scheme 1). Various physical chemistry techniques have been used to characterize the structure of the polymer. Density functional theory (DFT), a useful technique to define the host-guest interactions and the catalytic mechanism, has been employed to investigate the nature of the inclusion process on the reaction. Additionally, a plausible oxidation mechanism has been proposed based on XPS, FTIR and other experimental results.

\section{Experimental and computational section}

\subsection{Preparation of $\beta-C D C P$}

$\beta$-CDCP was synthesized by reacting $\beta$-CD with epichlorohydrin cross-linked cellulose in a $\mathrm{NaOH}$ solution according to a procedure reported earlier with some modifications [23]. $2 \mathrm{~g}$ of cellulose was dispersed in $30 \mathrm{~mL}$ of $25 \% \mathrm{NaOH}$ solution. $7 \mathrm{~mL}$ of epichlorohydrin was then added dropwise to the mixture. The mixture was further stirred at $40{ }^{\circ} \mathrm{C}$ for $4 \mathrm{~h}$. Subsequently, the intermediate was filtered, washed by acetone and water to remove epichlorohydrin thoroughly, and then centrifuged and rinsed with water to remove any residual $\mathrm{NaOH}$ and any water-soluble impurities until the $\mathrm{pH}$ of the supernatant approached neutral. The intermediate was dried under vacuum at $40{ }^{\circ} \mathrm{C}$ for $12 \mathrm{~h}$ to obtain epichlorohydrin modified cellulose (CE).

$2 \mathrm{~g} \mathrm{CE}$ dispersed in $30 \mathrm{~mL} \mathrm{NaOH}$ solution (25\%) was mixed with $0.7 \mathrm{~g}$ of $\beta-\mathrm{CD}$, and the mixture was stirred at $40{ }^{\circ} \mathrm{C}$ for $6 \mathrm{~h}$. The solid product was separated by centrifugation and washed until neutral with distilled water. Finally, it was dried at $60{ }^{\circ} \mathrm{C}$ for $24 \mathrm{~h}$ under vacuum. The amount of $\beta$-CD immobilized on the cellulose was determined to be $0.146 \mathrm{mmol} / \mathrm{g}$ by the previously reported method [24].

\subsection{Preparation of the inclusion complex of cinnamaldehyde with $\beta-C D C P$}

$\beta$-CDCP was completely dispersed in $25 \mathrm{~mL}$ deionized water. An equimolar amount of cinnamaldehyde was then added. The solution was stirred at $25{ }^{\circ} \mathrm{C}$ and $250 \mathrm{r} / \mathrm{min}$ for $1 \mathrm{~h}$, and then centrifuged. The resultant solid was washed with distilled water to remove any residual substrate, and dried at $50{ }^{\circ} \mathrm{C}$ for

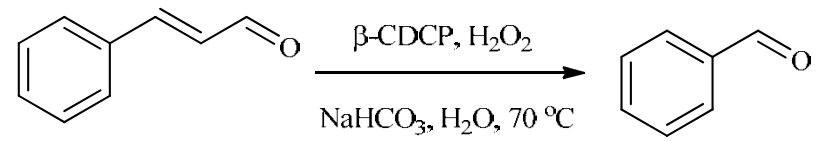

Scheme 1. Oxidation of cinnamaldehyde to benzaldehyde catalyzed by $\beta$-CDCP.
$12 \mathrm{~h}$ under vacuum. The product was stored in a desiccator before use.

\subsection{Characterization of $\beta$-CDCP and its inclusion complex}

FTIR spectra (400-4000 $\mathrm{cm}^{-1}$ ) were recorded on a Bruker TENSOR 37 FT-IR spectrometer. XPS spectra were measured on a Vacuum Generator ESCALAB 250 spectrometer with an $\mathrm{Al}$ $K_{\alpha}$ monochromatic X-ray source and a hemispherical analyzer. A fixed analyzer pass energy of $150 \mathrm{eV}$ was used for the survey scans, and high-resolution scans of core-level regions were recorded using a $20 \mathrm{eV}$ pass energy. All core-level spectra were referenced to the $\mathrm{C} 1 \mathrm{~s}$ neutral carbon peak at $284.5 \mathrm{eV}$ and obtained at a takeoff at $90^{\circ}$ to the sample surface.

\subsection{General procedure for oxidation of cinnamaldehyde}

$1 \mathrm{mmol}$ of cinnamaldehyde was dissolved in $25 \mathrm{~mL}$ of deionized water at $70{ }^{\circ} \mathrm{C}$ in a $100 \mathrm{~mL}$ three-necked flask equipped with a reflux condenser and electromagnetic stirrer. $1 \mathrm{~g}$ of $\beta$-CDCP was then added and the mixture was stirred for $30 \mathrm{~min}$. $2 \mathrm{mmol}$ of $\mathrm{NaHCO}_{3}$ dissolved in $4 \mathrm{~mL}$ of $30 \% \mathrm{H}_{2} \mathrm{O}_{2}$ was slowly added dropwise. The mixture was stirred at $70{ }^{\circ} \mathrm{C}$ for $3 \mathrm{~h}$, and then extracted with ethyl acetate and centrifuged. The organic phase was analyzed by GC-MS with naphthalene as an internal standard. The data were reproducible to within $5 \%$.

\subsection{Kinetic experiments}

Cinnamaldehyde ( $1 \mathrm{mmol}$ ) was dissolved in $100 \mathrm{~mL}$ of deionized water in a $100 \mathrm{~mL}$ three-necked flask equipped with a reflux condenser and magnetic stirrer, before $0.5 \mathrm{~g}$ of $\beta$-CDCP was added. The mixtures were heated to reaction temperature $\left(30,40,50\right.$ or $\left.60{ }^{\circ} \mathrm{C}\right)$ and stirred for $30 \mathrm{~min}$. Then, $2 \mathrm{~mL}$ of $30 \%$ $\mathrm{H}_{2} \mathrm{O}_{2}$ and $1.5 \mathrm{mmol}$ of $\mathrm{NaHCO}_{3}$ were added rapidly and the oxidation reaction occurred. $0.5 \mathrm{~mL}$ of the reaction mixture was sampled at 20-min intervals. Each sample was diluted to 100 $\mathrm{mL}$ with deionized water and its absorbance at $290 \mathrm{~nm}$ was measured to quantify the amount of cinnamaldehyde.

\subsection{Computer modeling of the inclusion complex of cinnamaldehyde or benzaldehyde with $\beta$-CDCP}

\subsubsection{Thermodynamic properties of the inclusion complex in a vacuum}

Molecular dynamic (MD) simulations were performed with Material Studio version 4.3 (Accelrys, Boston, USA). A COMPASS force field was employed in all MD simulations according to previous reports [25]. The structure of $\beta$-CD with cinnamaldehyde or benzaldehyde was first energy optimized, and then subjected to an inclusion molecule. The models were constructed at a fixed 1:1 molar ratio of cinnamaldehyde or benzaldehyde to $\beta$-CD in $\beta$-CDCP. The binding energy (BE) can be expressed as:

$$
\mathrm{BE}=E_{\mathrm{C}}-E_{\mathrm{G}}-E_{\mathrm{H}}
$$

where $E_{\mathrm{C}}, E_{\mathrm{G}}$, and $E_{\mathrm{H}}$ were the total energy of inclusion complex, guests, and host, respectively. $\beta$-CDCP was used as the host, and 
cinnamaldehyde or benzaldehyde was selected as the model guest. The total energy of $E_{\mathrm{C}}, E_{\mathrm{G}}$, and $E_{\mathrm{H}}$ can be expressed as:

$$
E_{\mathrm{C}}=E_{\mathrm{b}}+E_{\mathrm{n}}+E_{\mathrm{vdW}}+E_{\mathrm{E}}
$$

where $E_{\mathrm{b}}$ is the valence energy, $E_{\mathrm{n}}$ is the non-bond energy, $E_{\mathrm{vdW}}$ is the van der Waals interaction energy, and $E_{\mathrm{E}}$ is the electrostatic energy.

\subsubsection{Thermodynamic properties in water}

The amorphous structure of the host-guest inclusion complex was generated under periodic boundary conditions. The lengths of the cell were over $2.0 \mathrm{~nm} \times 2.0 \mathrm{~nm}$ for the inclusion complexes with 500 molecules of water in the system. The density of $\beta$-CD, cinnamaldehyde, and benzaldehyde in the systems was maintained in Synthia units at $1.27,1.05$, and $1.04 \mathrm{~g} / \mathrm{cm}^{3}$ at $25{ }^{\circ} \mathrm{C}$. Of the configurations, only the lowest energy one, as calculated by molecular mechanics, was chosen to be the initial configuration. 5000 steps of energy minimization were executed with Smart algorithm to remove unfavorable interactions in the initial configuration. A 100-ps molecular dynamic simulation was performed using normal pressure and temperature conditions with a time step of $1 \mathrm{fs}$ in the range of $0-37^{\circ} \mathrm{C}$. A cut-off distance of $0.85 \mathrm{~nm}$ and a buffer of $0.05 \mathrm{~nm}$ were adopted to minimize calculations of non-bonding interactions. Electrostatic charges in the model were calculated by the charge equilibration method. The duration of the equilibration dynamics was 100 ps. Models of inclusion complex were then subjected to molecular dynamics at least 1000 ps. The hydrogen calculation was performed by hydrogen build following this geometric parameter: the hydrogen-acceptor distance < $0.3 \mathrm{~nm}$ and the donor-hydrogen-acceptor angle $>90.0^{\circ}$ [20].

The binding energy (BE) in water-explicit system can be calculated as follows:

$$
\mathrm{BE}_{(\mathrm{sol})}=E_{\mathrm{C}(\mathrm{sol})}-E_{\mathrm{G}(\mathrm{sol})}-E_{\mathrm{H}(\mathrm{sol})}
$$

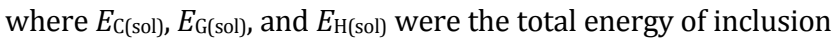
complex, guests, and host in water system, respectively.

\section{Results and discussion}

\subsection{Characterization of $\beta-C D C P$}

The FTIR spectra of cellulose, $\beta$-CD and $\beta$-CDCP are shown in Fig. 1(a). The IR spectrum of $\beta$-CDCP is similar to that of $\beta$-CD, indicating the $\beta$-CD in $\beta$-CDCP has not changed shape. The characteristic peak of the $-\mathrm{OH}$ stretching vibration at 3446 $\mathrm{cm}^{-1}$ for $\beta$-CDCP is stronger than that of cellulose. The increase of intensity could be attributed to the presence of more $-\mathrm{OH}$ groups in $\beta$-CDCP. The $\mathrm{C}-\mathrm{O}-\mathrm{C}$ band at $1030 \mathrm{~cm}^{-1}$ is observed in $\beta$-CDCP, whereas no band which can be assigned to the epoxy ring is observed at $1260 \mathrm{~cm}^{-1}$. This result strongly suggests that the epoxy ring of epichlorohydrin molecule has been opened in the hydrolysis reaction to form the polymer framework. In addition, the peak at $890 \mathrm{~cm}^{-1}$ is a characteristic band of $\alpha-(1,4)$ glucopyranose in $\beta$-CD [26], which provides some evidence that $\beta$-CD has been immobilized successfully on the cellulose through cross-linking with epichlorohydrin. XPS also provides some quantitative information on the surface composition of cellulose before and after modification. The C1s and 01s bands
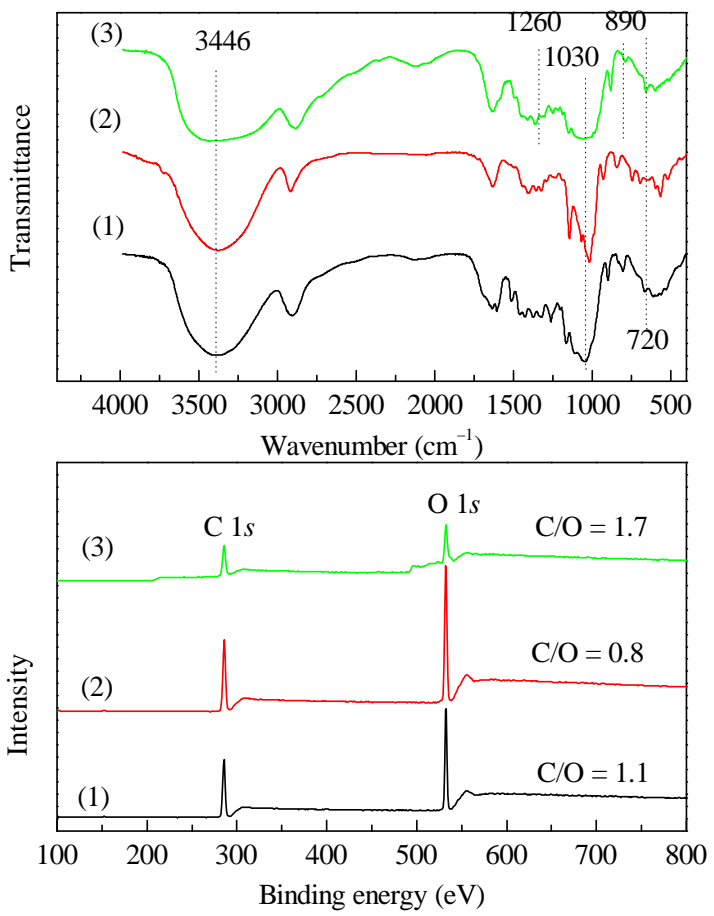

Fig. 1. (a) FTIR spectra of cellulose (1), $\beta$-CD (2), and $\beta$-CDCP (3); (b) XPS profiles of $\beta$-CD (1), cellulose (2), and $\beta$-CDCP (3).

of $\beta$-CDCP, cellulose and $\beta$-CD are shown in Fig. $1(b)$. The results clearly indicate that $\beta$-CDCP has a higher surface $\mathrm{C} / \mathrm{O}$ ratio (1.7) than cellulose $(0.8)$.

\subsection{Catalytic activities of $\beta$-CDCP}

Oxidation of cinnamaldehyde to benzaldehyde was carried out at $70{ }^{\circ} \mathrm{C}$ as shown in Scheme 1 . The performance of different catalysts is summarized in Table 1 . In order to allow comparison of catalytic effectiveness in terms of productivity per mass of catalyst, one separate specific activity was calculated for each catalyst, with respect to the dry mass of the catalyst as follows [27]:

Specific activity $=[$ substrate $](\mu \mathrm{mol}) \times$ Yield $(\%) /$ catalyst $(\mathrm{g})$

$$
\times \text { Time (min) }
$$

From Table 1, $\beta$-CDCP gave higher benzaldehyde yield and specific activity than $\beta-C D$, and the results greatly decreased in the absence of catalyst. In addition, similar results were obtained with cellulose and CE as the catalyst, indicating that their contribution to the benzaldehyde yield was very low. There-

Table 1

Catalytic performance of various catalysts.

\begin{tabular}{lcccc}
\hline Catalyst & $\begin{array}{c}\text { Time }^{\mathrm{a}} \\
(\mathrm{min})\end{array}$ & $\begin{array}{c}V_{0} \\
(\mu \mathrm{mol} / \mathrm{min})\end{array}$ & $\begin{array}{c}\text { Specific activity } \\
(\mu \mathrm{mol} /(\mathrm{min} \cdot \mathrm{g}))\end{array}$ & $\begin{array}{c}\text { Yield } \\
(\%)\end{array}$ \\
\hline None & 180 & 1.00 & 1.00 & 18 \\
Cellulose & 180 & 1.05 & 1.05 & 19 \\
$\beta$-CD & 120 & 3.17 & 2.79 & 38 \\
$\beta$-CDCP & 90 & 7.89 & 7.89 & 71 \\
CE & 180 & 1.00 & 1.00 & 18 \\
\hline
\end{tabular}

Reaction conditions: cinnamaldehyde $(1 \mathrm{mmol}), \mathrm{H}_{2} \mathrm{O}(25 \mathrm{~mL}), 70{ }^{\circ} \mathrm{C}$, $30 \% \mathrm{H}_{2} \mathrm{O}_{2}(4 \mathrm{~mL}), \mathrm{NaHCO}_{3}(2 \mathrm{mmol}), 500 \mathrm{r} / \mathrm{min}$.

a Reaction time to achieve the maximum yield. 


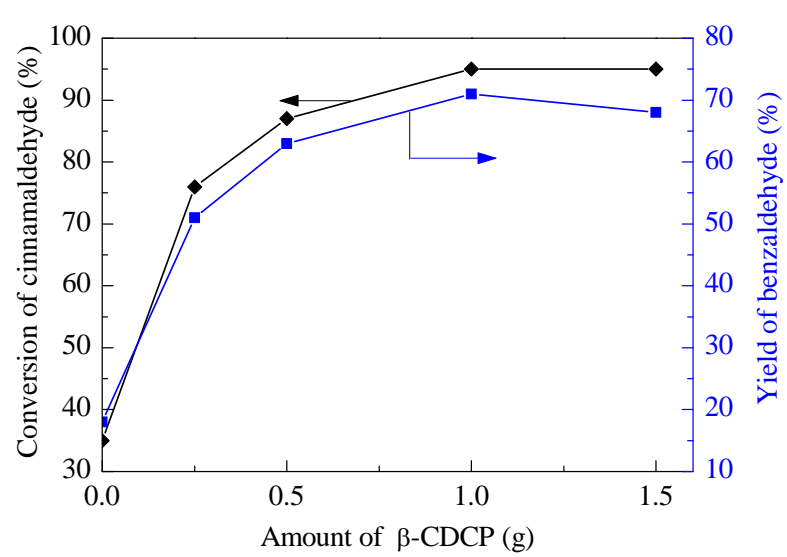

Fig. 2. Effect of $\beta$-CDCP loading on the cinnamaldehyde oxidation. Reaction conditions: cinnamaldehyde $(1 \mathrm{mmol}), 30 \% \mathrm{H}_{2} \mathrm{O}_{2}(4 \mathrm{~mL}), \mathrm{NaHCO}_{3}$ ( $2 \mathrm{mmol}), \mathrm{H}_{2} \mathrm{O}(25 \mathrm{~mL}), 70^{\circ} \mathrm{C}, 3 \mathrm{~h}, 500 \mathrm{r} / \mathrm{min}$.

fore, the high yield of benzaldehyde was not due to the presence of cellulose or CE. These studies suggest that the weak interactions involved in the inclusion of substrate in the $\beta$-CD are important for the selective oxidation of cinnamaldehyde. However, the synergistic effects based on the weak interactions between $\beta$-CD and the functional group of cellulose played a crucial role in the high efficiency of the oxidation of cinnamaldehyde.

\subsection{Effect of reaction conditions}

\subsubsection{Effect of $\beta$-CDCP loading}

The effect of the $\beta$-CDCP loading on the oxidation of cinnamaldehyde to benzaldehyde was also investigated by varying the catalyst amount from 0 to $1.5 \mathrm{~g}$, as shown in Fig. 2 .

The conversion of cinnamaldehyde and yield of benzaldehyde increased as the catalyst amount increased, coupled with a slight enhancement in selectivity for benzaldehyde. Maximal conversion (ca. 95\%) was obtained with $1.0 \mathrm{~g}$ of catalyst. This oxidation reaction gave a $71 \%$ yield of benzaldehyde. After this, excessive $\beta$-CDCP leads to unwanted side reactions and decrease the yield of benzaldehyde.

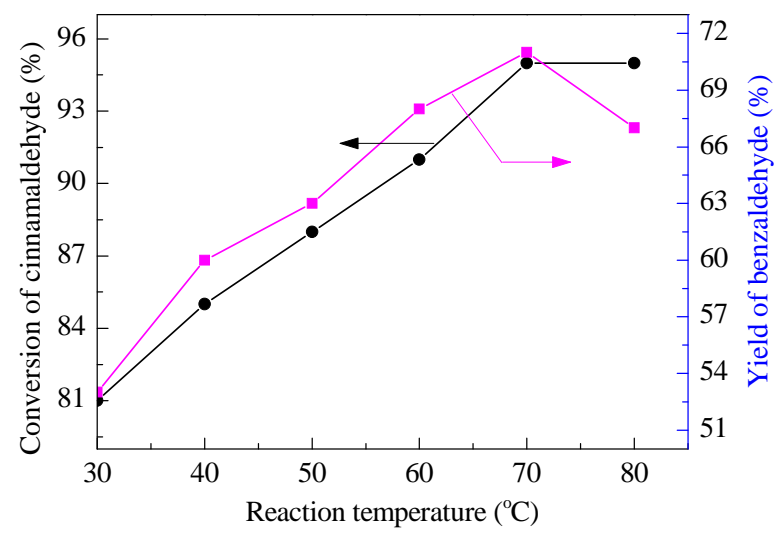

Fig. 3. Effect of reaction temperature on cinnamaldehyde oxidation. Reaction conditions: cinnamaldehyde ( $1 \mathrm{mmol}), \beta$-CDCP $(1.0 \mathrm{~g}), 30 \%$ $\mathrm{H}_{2} \mathrm{O}_{2}(4 \mathrm{~mL}), \mathrm{NaHCO}_{3}(2 \mathrm{mmol}), \mathrm{H}_{2} \mathrm{O}(25 \mathrm{~mL}), 3 \mathrm{~h}, 500 \mathrm{r} / \mathrm{min}$.
Table 2

Effect of the amount of $\mathrm{H}_{2} \mathrm{O}_{2}$ on the oxidation of cinnamaldehyde.

\begin{tabular}{lccc}
\hline Entry & $\mathrm{H}_{2} \mathrm{O}_{2}(\mathrm{~mL})$ & Conversion $(\%)$ & Yield (\%) \\
\hline 1 & 0 & 14 & 8 \\
2 & 1 & 70 & 56 \\
3 & 2 & 88 & 60 \\
4 & 3 & 91 & 67 \\
5 & 4 & 95 & 71 \\
6 & 5 & 95 & 70 \\
\hline
\end{tabular}

Reaction conditions: cinnamaldehyde (1 mmol), $\beta$-CDCP (1.0 g), Na$\mathrm{HCO}_{3}(2 \mathrm{mmol}), \mathrm{H}_{2} \mathrm{O}(25 \mathrm{~mL}), 70{ }^{\circ} \mathrm{C}, 3 \mathrm{~h}, 500 \mathrm{r} / \mathrm{min}$.

\subsubsection{Effect of reaction temperature}

The effect of reaction temperature on the oxidation of cinnamaldehyde was investigated, as shown in Fig. 3.

The results indicated that increasing the temperature improved the conversion of cinnamaldehyde and yield of benzaldehyde significantly, suggesting the reaction was highly sensitive to the temperature. 95\% cinnamaldehyde conversion and $71 \%$ benzaldehyde yield were obtained at $70{ }^{\circ} \mathrm{C}$. However, when the temperature exceeded $70{ }^{\circ} \mathrm{C}$, the yield decreased due to decomposition of $\mathrm{H}_{2} \mathrm{O}_{2}$. Lower temperatures are also preferred to reduce the decomposition of benzaldehyde [14]. Thus the optimal temperature for the oxidation of cinnamaldehyde to benzaldehyde was $70^{\circ} \mathrm{C}$.

\subsubsection{Effect of the $\mathrm{H}_{2} \mathrm{O}_{2}$ amount}

$\mathrm{H}_{2} \mathrm{O}_{2}$ is an environmentally-friendly oxidant since water is the sole byproduct $[28,29]$. The amount of $\mathrm{H}_{2} \mathrm{O}_{2}$ used in the system also influenced the oxidation of cinnamaldehyde. As shown in Table 2, the conversion increased with increasing amounts of $\mathrm{H}_{2} \mathrm{O}_{2}$. 95\% conversion of cinnamaldehyde and $71 \%$ yield of benzaldehyde were obtained with $4 \mathrm{~mL}$ of $\mathrm{H}_{2} \mathrm{O}_{2}$. Further increase of $\mathrm{H}_{2} \mathrm{O}_{2}$ amount did not improve the conversion.

\subsubsection{Effect of the $\mathrm{NaHCO}_{3}$ amount}

$\mathrm{H}_{2} \mathrm{O}_{2}$ is a rather weak oxidant in the absence of an activator. According to previously published results [28,30], the bicarbonate- $\mathrm{H}_{2} \mathrm{O}_{2}$ system is a simple and efficient method for the activation of $\mathrm{H}_{2} \mathrm{O}_{2}$. The effect of the $\mathrm{NaHCO}_{3}$ amount on the

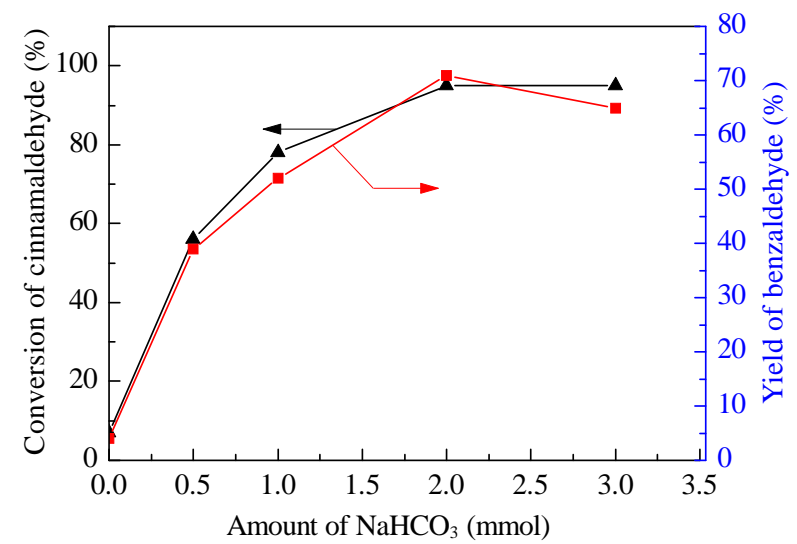

Fig. 4. Effect of the amount of $\mathrm{NaHCO}_{3}$ on cinnamaldehyde oxidation. Reaction conditions: cinnamaldehyde $(1 \mathrm{mmol}), 30 \% \mathrm{H}_{2} \mathrm{O}_{2}(4 \mathrm{~mL}), \mathrm{H}_{2} \mathrm{O}$ (25 mL), $70^{\circ} \mathrm{C}, 3 \mathrm{~h}, 500 \mathrm{r} / \mathrm{min}$. 
oxidation of cinnamaldehyde was investigated and the results are presented in Fig. 4. The $\mathrm{NaHCO}_{3}$ amount played an important role in the oxidation of cinnamaldehyde. In the absence of $\mathrm{NaHCO}_{3}$, the conversion of cinnamaldehyde and yield of benzaldehyde were only $7 \%$ and $4 \%$, respectively. When the $\mathrm{NaHCO}_{3}$ amount reached 2 mmol, 95\% conversion of cinnamaldehyde and $71 \%$ yield of benzaldehyde were obtained. The activation was considered to start with a combination of $\mathrm{H}_{2} \mathrm{O}_{2}$ and bicarbonate in an equilibrium process to produce peroxymonocarbonate (Eq. (5)).

$$
\mathrm{HCO}_{3}{ }^{-}+\mathrm{H}_{2} \mathrm{O}_{2}{ }^{-}=\mathrm{HCO}_{4}{ }^{-}+\mathrm{H}_{2} \mathrm{O}
$$

Peroxymonocarbonate is an active oxidant, with structure $\mathrm{HOOCO}_{2}^{-}$, which efficiently promotes the epoxidation of cinnamaldehyde, and further oxidation to benzaldehyde, which will be discussed later.

\subsection{Kinetic studies}

The oxidation rate of cinnamaldehyde in the presence of $\beta$-CDCP is shown in Fig. 5 (a). A linear relationship between $\ln \left(C_{0} / C_{t}\right)$ and time was observed, indicating the reaction follow pseudo-first-order kinetics:

$$
\ln \left(C_{0} / C_{t}\right)=k t
$$

Here, $C_{0}, C_{t}, t$, and $k$ are the initial cinnamaldehyde concentration, cinnamaldehyde concentration at $t$, reaction time, and the apparent reaction rate $\left(\mathrm{min}^{-1}\right)$, respectively. The slope of $\mathrm{ln}$ $\left(C_{0} / C_{t}\right)$ vs $t$ was used to calculate $k$.

The rate constant $k$ was calculated from Fig. 5 (a). It was found to increase from 0.00687 to $0.0357 \mathrm{~min}^{-1}$ when the

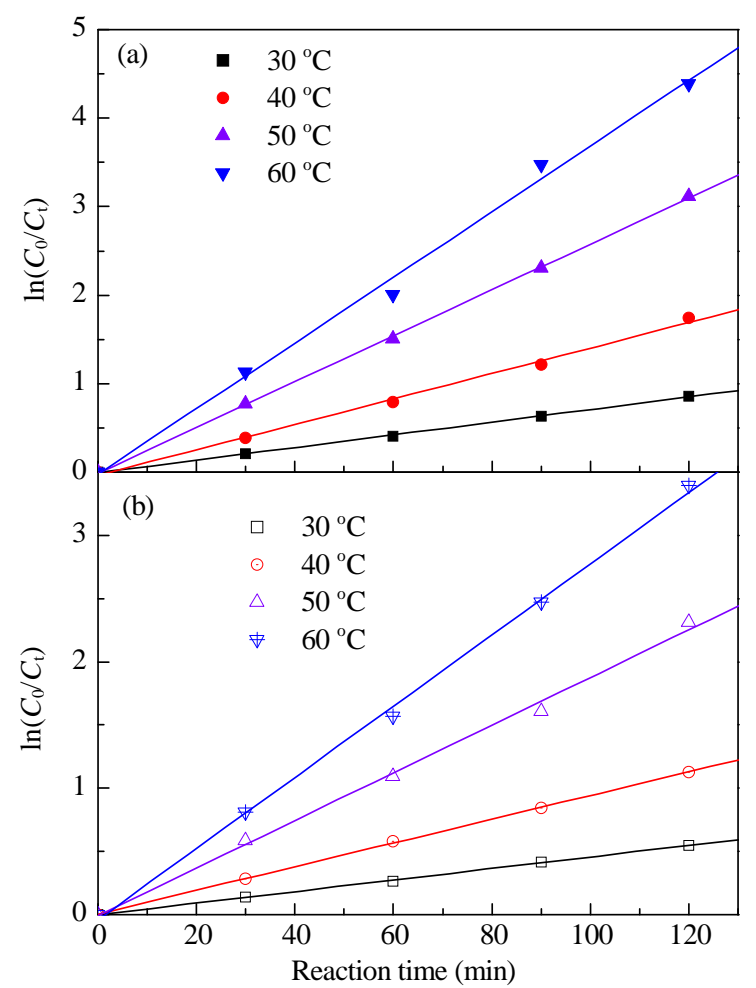

Fig. 5. Pseudo-first-order plots of cinnamaldehyde oxidation by the $\mathrm{H}_{2} \mathrm{O}_{2}-\mathrm{NaHCO}_{3}$ system at different reaction temperatures in the presence (a) and absence (b) of $\beta$-CDCP.

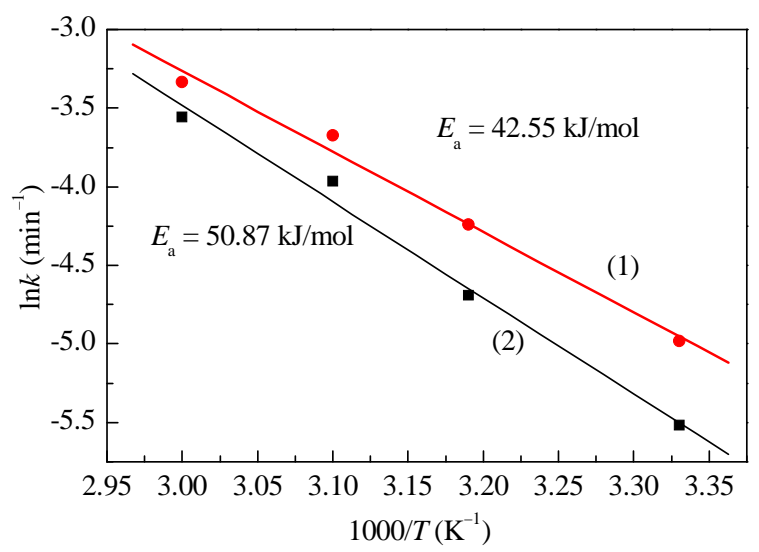

Fig. 6. Arrhenius plots of the rate constants for the cinnamaldehyde oxidation. (1) Presence of $\beta$-CDCP; (2) Absence of $\beta$-CDCP.

temperature was increased from 30 to $60{ }^{\circ} \mathrm{C}$.

Fitting results of the first-order kinetic model indicated the oxidation of cinnamaldehyde to benzaldehyde, in the absence of $\beta$-CDCP, and followed a pseudo-first-order kinetic model (Fig. 5 (b)). The rate constant increased from 0.00403 to $0.0286 \mathrm{~min}^{-1}$ as the temperature was increased from 30 to 60 ${ }^{\circ} \mathrm{C}$.

According to the Arrhenius equation:

$$
k=A \mathrm{e}^{-E \mathrm{a} / R T}
$$

Eq. (7) could be rearranged as Eq. (8):

$$
\ln k=\ln A-E \mathrm{a} / R T
$$

Arrhenius plots of $\ln k$ and $1 / T$ are shown in Fig. 6. The plots are linear and the activation energy $E_{\mathrm{a}}$ in the presence and absence of $\beta$-CDCP were calculated to be 42.55 and $50.87 \mathrm{~kJ} / \mathrm{mol}$, respectively. It is obvious that $\beta$-CDCP decreases the energy barrier of the oxidation.

\subsection{Recycling the catalyst}

Unlike free $\beta$-CD, the $\beta$-CDCP catalyst could be easily recovered from the reaction solution and reused. To examine its reusability, it was recovered by centrifugation after each batch. The obtained precipitate was washed with ethanol and deion-

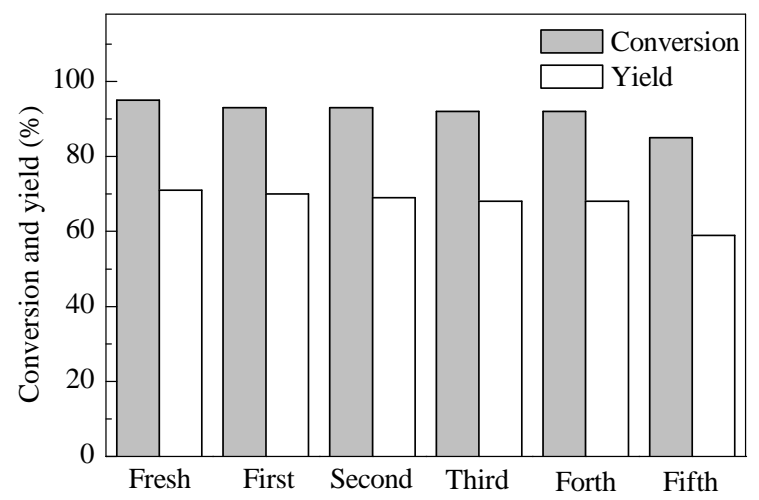

Fig. 7. Recyclability data of the catalyst for cinnamaldehyde oxidation. Reaction conditions: cinnamaldehyde $(1 \mathrm{mmol}), \beta$-CDCP $(1.0 \mathrm{~g}), \mathrm{H}_{2} \mathrm{O}$ (25 mL), 30\% $\mathrm{H}_{2} \mathrm{O}_{2}(4 \mathrm{~mL}), \mathrm{NaHCO}_{3}(2 \mathrm{mmol}), 70{ }^{\circ} \mathrm{C}, 3 \mathrm{~h}, 500 \mathrm{r} / \mathrm{min}$. 
ized water. After drying, the catalyst was reused for the next run. As shown in Fig. 7, the results indicate that the conversion and selectivity of the reused catalyst remain nearly constant for four cycles.

\subsection{Reaction mechanism investigation}

\subsubsection{FTIR analysis of the inclusion complex}

FTIR measurements can provide useful information about hydrogen bonds and the formation of inclusion complexes [31].

The IR spectra of $\beta$-CDCP, the inclusion complex, and cinnamaldehyde are shown in Fig. 8. The spectrum of the inclusion complex (2) is similar to that of $\beta$-CDCP (1), indicating that the structure of the inclusion complex and $\beta$-CDCP are similar. The stretching absorption of $\mathrm{C}-\mathrm{H}$ of the benzene ring at $3030 \mathrm{~cm}^{-1}$ and the absorption peak intensity of the $\mathrm{C}-\mathrm{H}$ in aldehyde group (-CHO) at 2820 and $2750 \mathrm{~cm}^{-1}$ disappeared in the IR spectrum of the inclusion complex. For cinnamaldehyde, the C-O stretching absorption at $1688 \mathrm{~cm}^{-1}$ shifted to $1668 \mathrm{~cm}^{-1}$ in inclusion complex. This could be attributed to cinnamaldehyde occupying the cavity of $\beta$-CD in $\beta$-CDCP. Furthermore, the $\mathrm{C}-\mathrm{O}-\mathrm{H}$ absorption in the inclusion complex at 1335 and 1250 $\mathrm{cm}^{-1}$ was much stronger than that in $\beta$-CDCP. These indicate the formation of hydrogen bonds between the hydroxyl groups of $\beta$-CD in $\beta$-CDCP and the carbonyl groups of cinnamaldehyde. Based on the discussion above, it is reasonable to conclude that a host-guest inclusion complex has been formed [32].

\subsubsection{XPS analysis of the inclusion complex}

XPS is useful for the analysis of specific interactions within the $\beta$-CDCP/cinnamaldehyde inclusion complex [33]. XPS spectra of $\mathrm{C} 1 s$ and $01 s$ in $\beta$-CDCP before and after cinnamaldehyde inclusion are shown in Fig. 9. The carbon signals shown in Fig. 9 (a) gave three different binding energies at 284.8, 286.6 and $287.9 \mathrm{eV}$, which are attributed to $\mathrm{C}-\mathrm{C}$ (or $\mathrm{C}-\mathrm{H}$ ), $\mathrm{C}-\mathrm{O}$, and
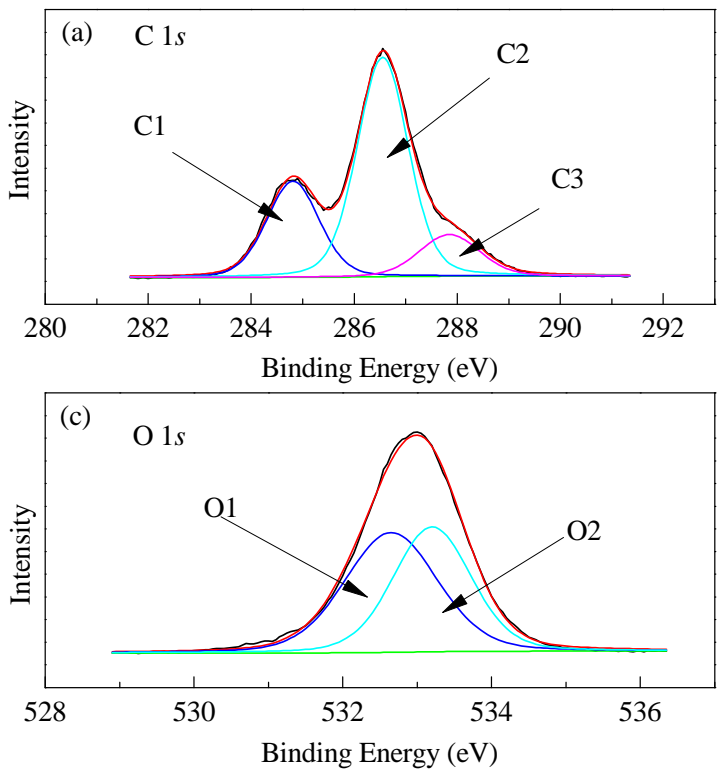

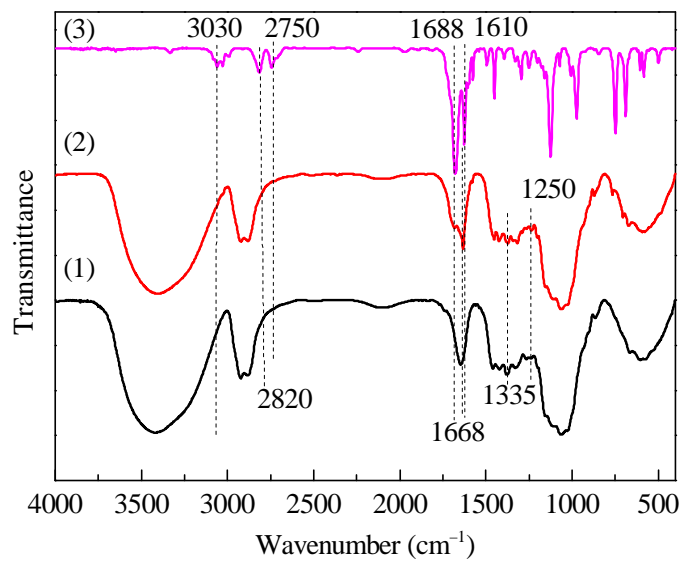

Fig. 8. FTIR spectra of $\beta$-CDCP (1), the inclusion complex of $\beta$-CDCP and cinnamaldehyde (2), and cinnamaldehyde (3).

$\mathrm{C}=\mathrm{O}$ (or $\mathrm{O}-\mathrm{C}-\mathrm{O}$ ) in the stem chain, respectively $[34,35]$. Similarly, Fig. 9 (c) shows the $01 s$ spectrum with two peaks at 532.8 and $533.7 \mathrm{eV}$ which are assigned to $\mathrm{O}-\mathrm{H}$ and $\mathrm{O}=\mathrm{C}$, respectively $[35,36]$. Comparing the binding energy of each element in $\beta$-CDCP and the $\beta$-CDCP/cinnamaldehyde inclusion complex, the $\mathrm{C} 1 s$ binding energy of $\mathrm{C}=0$ in the inclusion complex decreased from 287.9 to $282.2 \mathrm{eV}$ (Fig. 9 (b)), and $01 \mathrm{~s}$ binding energy of $\mathrm{O}-\mathrm{C}$ in the inclusion complex decreased from 533.5 to $533.2 \mathrm{eV}$ (Fig. 9 (d)). Moreover, two peaks at 287.2 and $531.6 \mathrm{eV}$ were detected, which were assigned to the $\mathrm{C} 1 \mathrm{~s}$ of $\mathrm{C}-\mathrm{H} \cdots \mathrm{O}$ and the $\mathrm{O} 1 \mathrm{~s}$ of the $\mathrm{H}-\mathrm{O} \cdots \mathrm{O}$ group in the inclusion complex, respectively. All these results provide additional evidence of the interaction between the surface $\mathrm{C}-\mathrm{OH}$ group of the $\beta$-CDCP and $\mathrm{C}=0$ group of cinnamaldehyde via a hydrogen bond.

\subsubsection{Optimized structure of the inclusion complexes}

To investigate the binding interaction between equimolar
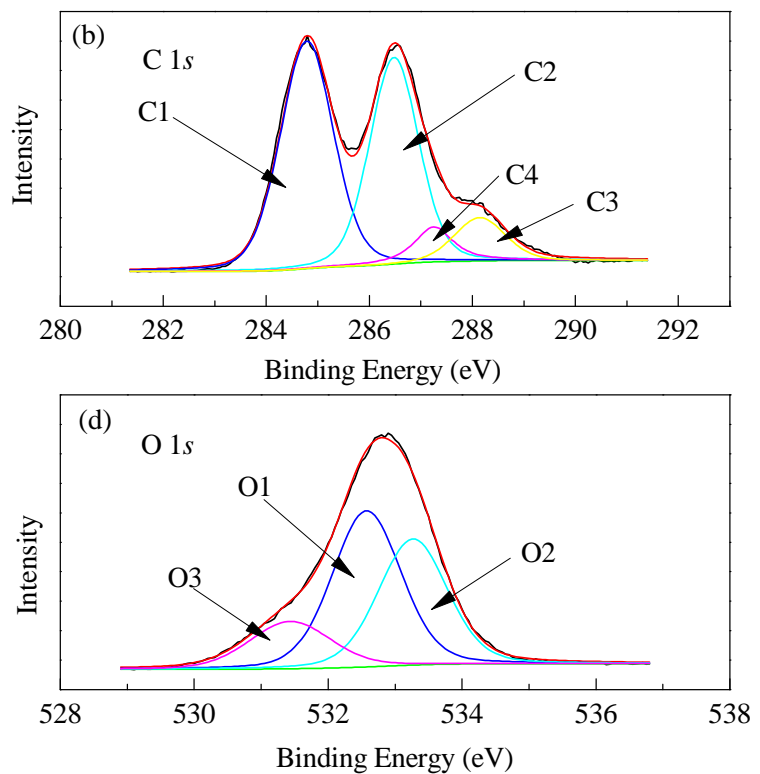

Fig. 9. XPS of C $1 s(\mathrm{a})$ and $01 s$ (c) core level spectra of $\beta$-CDCP, and C $1 s$ (b) and $01 s$ (d) core level spectra of the $\beta$-CDCP/cinnamaldehyde inclusion complex. 
(a)

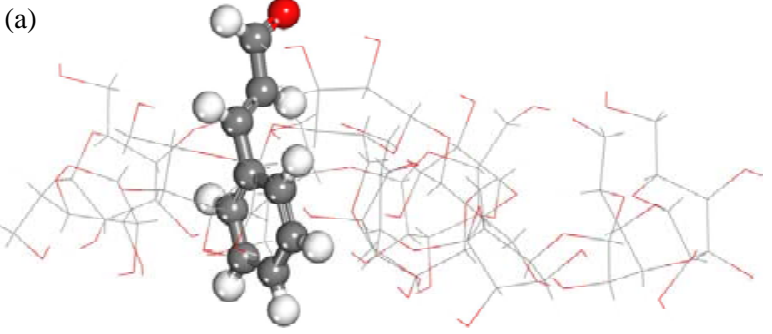

(b)

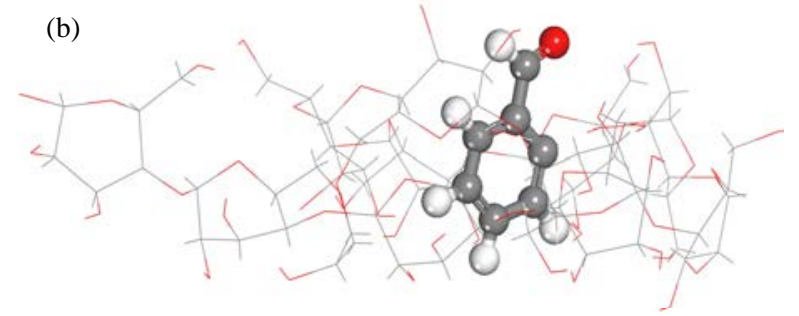

Fig. 10. Structure at the energy minimum obtained from the Forcite calculations for the $\beta$-CDCP guest complexes. (a) $\beta$-CDCP/cinnamaldehyde; (b) $\beta$-CDCP/benzaldehyde. Both seen from the side of the hydroxyl rim of the $\beta$-CD cavity in $\beta$-CDCP.

Table 3

Number, type, bond length $(r)$ and bond angle $(A)$ calculated by the Forcite method.

\begin{tabular}{|c|c|c|c|c|c|}
\hline \multirow{2}{*}{$\begin{array}{l}\text { Inclusion } \\
\text { complex }\end{array}$} & \multirow{2}{*}{ Type } & \multirow{2}{*}{$r / n m$} & \multirow{2}{*}{$A /\left({ }^{\circ}\right)$} & \multicolumn{2}{|c|}{$\mathrm{BE}(\mathrm{kJ} / \mathrm{mol})$} \\
\hline & & & & Vacuum & Water \\
\hline$\beta$-CDCP/cinnamaldehyde & $\mathrm{O}-\mathrm{H} \cdots \mathrm{O}-\mathrm{C}$ & 0.2104 & 125.3 & -63.32 & -60.49 \\
\hline$\beta$-CDCP/benzaldehyde & $\mathrm{O}-\mathrm{H} \cdots \mathrm{O}-\mathrm{C}$ & 0.2393 & 114.4 & -32.24 & -28.45 \\
\hline
\end{tabular}

amounts of cinnamaldehyde or benzaldehyde with $\beta$-CDCP, the optimized structure at the energy minimum for the $\beta$-CDCP guest complexes are shown in Fig. 10. The number of hydrogen bonds, the type, bond length $(r)$, and bond angle $(A)$ as calculated by the Forcite program package are shown in Table 3.

As shown in Fig. 10, the hydrophobic moieties of cinnamaldehyde and benzaldehyde molecules are enclosed within $\beta$-CD. The hydrophilic parts of the cinnamaldehyde and benzaldehyde molecules are exposed to an aqueous environment and associate with water molecules. The optimized geometries in Table 3 revealed that the shortest distance between the 0 atom of carbonyl in cinnamaldehyde and the $\mathrm{H}$ atom of the hydroxyl group was $0.2104 \mathrm{~nm}$, and the shortest distance between oxygen atom of carbonyl in benzaldehyde and hydrogen atom of the hydroxyl group was $0.2393 \mathrm{~nm}$. These $\mathrm{O}-\mathrm{H} \cdots \mathrm{O}$ bond angles were $125.3^{\circ}$ and $114.4^{\circ}$, respectively. The results indicated that the hydrogen bond interactions played a crucial role in the cinnamaldehyde/ $\beta$-CDCP and benzaldehyde/ $\beta$-CDCP complexes. The existence of a hydrogen bond effectively promotes substrate specificity of $\beta$-CDCP, significantly improving the selectivity towards benzaldehyde. As previously reported [37], the more negative the binding energy is, the more thermodynamically favorable the inclusion complex. From Table 4, the negative binding energy change clearly demonstrates that $\beta$-CDCP can form stable complexes with cinnamaldehyde and benzaldehyde, which was confirmed by calculations. The binding energy of $\beta$-CDCP/cinnamaldehyde (vacuum) $(-63.32 \mathrm{~kJ} / \mathrm{mol})$ was more negative than $\beta$-CDCP/benzaldehyde (vacuum) $(-32.24 \mathrm{~kJ} / \mathrm{mol})$ as calculated by the Forcite method. The binding energy for the inclusion complex of cinnamaldehyde/ $\beta$-CDCP (vacuum) was $-31.08 \mathrm{~kJ} / \mathrm{mol}$ lower than that of benzaldehyde/ $\beta$-CDCP (vacuum). This relationship was also seen when the binding energy was calculated in water. It further confirms that the complex of $\beta$-CDCP/cinnamaldehyde is much more stable than that of $\beta$-CDCP/benzaldehyde.

The recently reported results also indicate the difference between the two binding energy of cinnamaldehyde and benzaldehyde with $\beta$-CDCP is the basis for the selective separation of different substrates via $\beta$-CD inclusion $[31,37]$. The binding energy for the complex of $\beta$-CDCP/cinnamaldehyde $(-60.49$ $\mathrm{kJ} / \mathrm{mol}$ ) in water was much lower than that of the $\beta$-CDCP/ benzaldehyde $(-28.45 \mathrm{~kJ} / \mathrm{mol})$. Therefore, cinnamaldehyde is preferred in the hydrophobic cavity, while the benzaldehyde product tends to escape from the cavities of $\beta$-CD. Based on the DFT results, substrate specificity and mass transfer of $\beta$-CDCD significantly improves the catalytic activity and selectivity.

\subsubsection{Reaction mechanism for the oxidation of cinnamaldehyde to benzaldehyde}

Based on above results, a reaction mechanism has been proposed for the oxidation of cinnamaldehyde catalyzed by $\mathrm{NaHCO}_{3}-\mathrm{H}_{2} \mathrm{O}_{2}$ in the presence of $\beta$-CDCP. For the mechanism, a basic assumption is that the essential functional sites are in the $\beta$-CD cavities. First, $\beta$-CD in the $\beta$-CDCP and cinnamaldehyde form an inclusion complex via intermolecular hydrogen bonding through a $\mathrm{O}-\mathrm{H} \cdots \mathrm{O}$ bond at the second rim of $\beta$-CD (Scheme $2)$. The host-guest interaction between cinnamaldehyde and parent $\beta$-CD has been verified by ${ }^{1} \mathrm{H}$ NMR and ROESY as previously reported [14]. Nucleophilic attack by a hydroxide ion from the hydrolysis of $\mathrm{NaHCO}_{3}$ on the substrate gives benzaldehyde as a minor product. The result is in accordance with a previous report [14]. Second, $\mathrm{H}_{2} \mathrm{O}_{2}$ and bicarbonate combine in an equilibrium process to produce peroxymonocarbonate $\mathrm{HOOCO}_{2}-[24,25]$. It is an active oxidant and efficiently promotes the epoxidation of cinnamaldehyde. Other non-covalent intermolecular interactions between $\beta$-CD and cinnamaldehyde also promote the nucleophilic oxidation. Large amounts of cinnamaldehyde are converted to the epoxide, and then it is further oxidized to benzaldehyde by peroxymonocarbonate. Finally, the catalyst is returned to its initial state. It should be mentioned that alkaline hydrolysis is slow, and only $8 \%$ yield of the product is derived from this route in the present catalytic system.

\subsection{Oxidation of various cinnamaldehyde derivatives}

In view of the efficient oxidation of cinnamaldehyde, oxidation of cinnamaldehyde derivatives has been also investigated and the results are listed in Table 4.

$\beta$-CD in the $\beta$-CDCP has been shown to form a host-guest complex with a substrate. This complexation depends on the size, shape and hydrophobicity of the guest molecule. In the present research, the oxidation of cinnamaldehyde derivatives could be carried out smoothly. However, 2-nitro-, 4-methoxy-, 


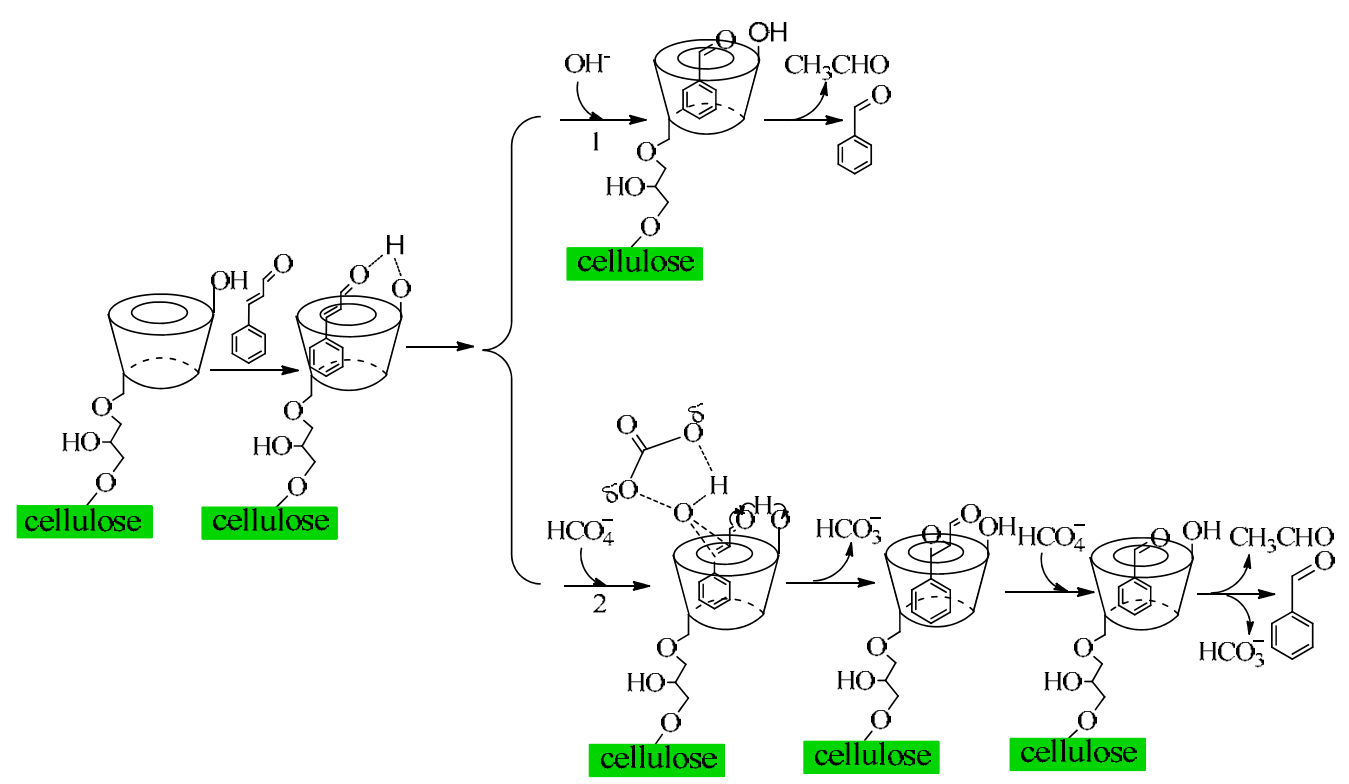

Scheme 2. Proposed mechanism for the oxidation of cinnamaldehyde catalyzed by $\mathrm{NaHCO}_{3}-\mathrm{H}_{2} \mathrm{O}_{2}$ in the presence of $\beta$-CDCP.

Table 4

$\beta$-CDCP catalyzed oxidation of cinnamaldehyde derivatives to the corresponding aldehydes in the presence of $\mathrm{NaHCO}_{3}-\mathrm{H}_{2} \mathrm{O}_{2}$.

\begin{tabular}{llccc}
\hline Entry & Reaction time $(\mathrm{h})$ & Reactant & Product & Yield (\%) \\
\hline 1 & 3.5 & 2-nitro-cinnamaldehyde & 2-nitro-benzaldehyde \\
2 & 4.5 & $\alpha$-methyl-cinnamaldehyde & $\alpha$-methyl-benzaldehyde \\
3 & 4 & 4-methoxy-cinnamaldehyde & 4-methoxy-benzaldehyde & 50 \\
4 & 3.5 & 2-hydroxy-cinnamaldehyde & 2-hydroxy-benzaldehyde & 67 \\
\hline
\end{tabular}

Reaction conditions: cinnamaldehyde derivative (1 mmol), $\beta$-CDCP (1.0 g), $\mathrm{NaHCO}_{3}(2 \mathrm{mmol}), 30 \% \mathrm{H}_{2} \mathrm{O}_{2}(4 \mathrm{~mL}), \mathrm{H}_{2} \mathrm{O}(25 \mathrm{~mL}), 70{ }^{\circ} \mathrm{C}, 500 \mathrm{r} / \mathrm{min}$.

and 2-hydroxy-cinnamaldehydes were more reactive than $\alpha$-methyl-cinnamaldehyde, indicating that the functional groups significantly affected the reaction. Conversely, the existence of an electron donating group lowered the reaction rate, demonstrating that the space required by the guest molecules is more important for efficient conversion than electronic effects in the present catalytic systems.

\section{Conclusions}

$\beta$-cyclodextrin-functionalized cellulose was successfully synthesized and utilized as a highly efficient heterogeneous catalyst for the synthesis of benzaldehyde. Compared with free $\beta-C D$, the use of cellulose as a supporting material can significantly improve the catalytic performance of immobilized $\beta$-CD.
These investigations have revealed that the synergistic effect of the weak interactions between the polymer-supported $\beta$-CD and the substrate, e.g. hydrogen bonding, lead to higher activity and selectivity. It was also found that reaction parameters play important roles in determining the catalytic performance of the catalysts. In addition, these heterogeneous catalysts demonstrated excellent reusability in the oxidation of cinnamaldehyde and cinnamaldehyde derivatives. The oxidation process is clean, safe, and reproducible under mild reaction conditions.

\section{References}

[1] Luo J Q, Tan R, Kong Y, Li C Y, Yin D H. Chin J Catal (骆建轻, 谭蓉, 孔瑜, 黎成勇, 银董红. 催化学报), 2012, 33: 1133

[2] Silverman R B. The Organic Chemistry of Enzyme-Catalyzed

\section{Graphical Abstract}

Chin. J. Catal., 2014, 35: 590-598 doi: 10.1016/S1872-2067(14)60056-5

\section{Synergistic effect of hydrogen bonding mediated selective synthesis of benzaldehyde in water}

Zujin Yang, Hongbing Ji*

Sun Yat-sen University

Enhanced selectivity for the product is mainly attributed to the substrate specificity of $\beta$-cyclodextrin-functionalized cellulose based on the synergistic effects of hydrogen bonding.

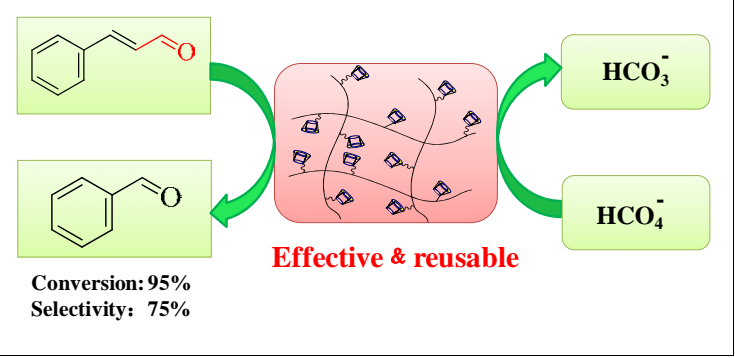


Reactions. San Diego: Academic Press, 2002

[3] Moreira Teixeira L S, Feijen J, van Blitterswijk C A, Dijkstra P J, Karperien M. Biomaterials, 2012, 33: 1281

[4] Grabowski S J. Chem Rev, 2011, 111: 2597

[5] Grabowski S J, Sokalski W A, Leszczynski J.J Phys Chem A, 2006, 110: 4772

[6] Schreiner P R. Chem Soc Rev, 2003, 32: 289

[7] Doyle A G, Jacobsen E N. Chem Rev, 2007, 107: 5713

[8] Tsogoeva S B. Eur JOrg Chem, 2007, (11): 1701

[9] Szejtli J. Chem Rev, 1998, 98: 1743

[10] Connors K A. Chem Rev, 1997, 97: 1325

[11] Breslow R, Zhang X J, Huang Y.J Am Chem Soc, 1997, 119: 4535

[12] Murakami Y, Kikuchi J I, Hisaeda Y, Hayashida O. Chem Rev, 1996, 96: 721

[13] Takahashi K. Chem Rev, 1998, 98: 2013

[14] Chen H Y, Ji H B. AIChE J, 2010, 56: 466

[15] Kumar A, Tripathi V D, Kumar P. Green Chem, 2011, 13: 51

[16] Ji H B, Huang L Q, Shen H M, Zhou X T. Chem Eng J, 2011, 167: 349

[17] Suh J H, Lee S H, Zoh K D. J Am Chem Soc, 1992, 114: 7916

[18] Martel B, Morcellet M. Eur Polym J, 1995, 31: 1089

[19] Hu C C, Chen W H, Liu C Y, Chen J L. J Incl Phenom Mol Recognit Chem, 1996, 23: 289

[20] Yang Z J, Ji H B. ACS Sustainable Chem Eng, 2013, 1: 1172

[21] Yang Z J, Zeng H, Zhou X T, Ji H B. Supramol Chem, 2013, 25: 233

[22] Fox S C, Li B, Xu D Q, Edgar K J. Biomacromolecules, 2011, 12: 1956

[23] Zhang L Z, Zhou J P, Zhang L N. Carbohyd Polym, 2013, 94: 386

[24] Glaied O, Dubé M, Chabot B, Daneault C. J Colloid Interf Sci, 2009,
333: 145

[25] Li Y Y, Liu J, Du G Y, Yan H, Wang, H Y, Zhang, H C, An W, Zhao W J, Sun T, Xin F E, Kong L, Li Y M, Hao A Y, Hao J C. J Phys Chem B, 2010, 114: 10321

[26] García-Zubiri Í X, González-Gaitano G, Sánchez M, Isasi J R. Vib Spectrosc, 2003, 33: 205

[27] Fernández-Lucas J, Condezo L A, Quezada M A, Sinisterra J V. Biotechnol Bioeng, 2008, 100: 213

[28] Richardson D E, Yao H R, Frank K M, Bennett D A. J Am Chem Soc, 2000, 122: 1729

[29] Zhao P P, Zhou Y, Liu Y Q, Wang J. Chin J Catal (赵萍萍, 周瑜, 刘阳 庆, 王军. 催化学报), 2013, 34: 2118

[30] Hosseini-Monfared H, Alavi S, Siczek M. Chin J Catal (催化学报), 2013, 34: 1456

[31] Yao H R, Richardson D E. J Am Chem Soc, 2000,122: 3220

[32] Yang Z J, Chai K G, Ji H B. Sep Purif Technol, 2011, 80: 209

[33] Tang B, Wang X, Wang G L, Yu C G, Chen Z Z. Talanta, 2006, 69: 113

[34] Zheng L Z, Wu S G, Lin X Q Nie L, Rui L, Yang X R. Macromolecules, 2002, 35: 6174

[35] Alila S, Ferraria A M, Botelho do Rego A M, Boufi S. Carbohyd Polym, 2009, 77: 553

[36] Burrell M C, Butts M D, Derr D, Genovese S, Perry R J, Appl Surf Sci, 2004, 227: 1

[37] Mutel B, Grimblot J, Dessaux 0, Goudmand P. Surf Interface Anal, 2000, 30: 401

[38] Ji H B, Long Q P, Chen H Y, Zhou X T, Hu X F. AIChE J, 2011, 57: 2341

\title{
氢键的协同作用驱动水中苯甲醛的合成
}

\author{
杨祖金，纪红兵 ${ }^{*}$ \\ 中山大学化学与化学工程学院, 广东省低碳化学与过程节能实验室, 广东广州510275
}

摘要: 以环氧氯丙烷作为交联溶剂合成和表征了纤维素功能化的 $\beta$-环糊精, 考察了这种超分子聚合物作为一种多相催化剂用于 苯甲醛的合成的催化性能. 结果表明, 该催化剂在温和的反应条件下具有较高的催化活性和选择性, 容易恢复和重新利用, 且活 性没有大的损失. 进一步研究指出, $\beta$-环糊精聚合物中的 $\beta$-环糊精能通过非极性共价键与肉桂醛形成主客包结物, 此外, $\beta$-环糊精 和纤维素的功能基团能与肉桂醛通过 $\mathrm{O}-\mathrm{H} \cdots \mathrm{O}$ 的氢键形成多重氢键的相互作用, 这种氢键的协同作用明显提高了催化剂的性能. 关键词: 纤维素功能化 $\beta$-环糊精; 氢键; 底物专一性; 肉桂醛氧化; 苯甲醛

收稿日期: 2013-11-23. 接受日期: 2014-01-03. 出版日期: 2014-04-20.

*通讯联系人. 电话: (020) 84113658; 传真: (020) 84113654电子信箱: jihb@mail.sysu.edu.cn

基金来源：国家自然科学基金(21376279, 21176268, 21036009); 广东省重大科技专项(2012A080103005); 广东省部产学研结合项 目(2011B090400439).

本文的英文电子版由Elsevier出版社在ScienceDirect上出版(http://www.sciencedirect.com/science/journal/18722067). 